\title{
The Application of Stylistics in British and American Literature Teaching
}

\author{
XU Li-mei, QU Lin-lin \\ Changchun University, Changchun, China
}

\begin{abstract}
Stylistics applies modern linguistic theory to the description of and analysis into varieties of language and their stylistic features. As such it may serve to investigate the styles of British and American literary works, thus facilitating the teaching of British and American literature. This paper, after surveying the basic stylistic theory and its relevance to research on and teaching of literature, illustrates how to effectively adopt the method of stylistic analysis in the teaching of British and American literature.
\end{abstract}

Keywords: stylistics, style, teaching of British and American literature

\section{Introduction}

In current college English teaching, people often ask the students to read a lot of literary works. While how to determine the selection criteria of literary works is of vital importance in the teaching process, which affects the teaching quality and students' knowledge for the depth and breadth of vision. In general, the criterion for the selection of literary works is its position in English literature, such as Shakespeare's works. For college students, the British and American literature works are very difficult to understand, but it is required reading in college English teaching. Therefore, it is very important to analyze the application of stylistics in British and American literature teaching.

\section{Stylistics}

\section{The Definition of Stylistics}

Stylistics is a branch of linguistics, and is also a comprehensive interdisciplinary subject in the study of characteristics, essence, and rules of text genre between linguistics, literary theory, aesthetics, psychology, and other disciplines. Such as Lazar (2005) says in "Stylistics and Language Practice" that stylistics is the overall performance of method and expression style purposefully selected in the specific communication field. It is formed in history, and accepted by the complete society as a whole system. Stylistics is the science used to study and discuss the system. Besides, it is also an independent branch of linguistics to express ideas more efficiently, and to study the principle of language materials chosen and used. 


\section{The Characteristics of Stylistics}

As a cross sectional much edge discipline, the characteristics of stylistics are to study a science of object with the application of another science method, thus making different scientific methods and objects organically. Stylistics is born in the border of several disciplines, and constantly penetrating to expand their areas.

Stylistics broke the traditional boundaries between disciplines which seem to be independent of each other, which makes some new face on disciplines such as linguistics and literary criticism. The character of stylistics making different field boundary promotes the interaction and penetration of different disciplines, and gradually tends to integrate. Besides, the character of borderline is also a reflection of modern science and technology development tendency for stylistics, which is namely the highly differentiated of science and technology and the highly integrated of mutual penetration of natural science and social science.

\section{The Application Analysis of Stylistics in British and American Literature Teaching}

In the teaching of English and American literature, how to guide students to master the language features of a literary text? How to use linguistic concepts and techniques to discuss these characteristics and sublimate it into a style? How to analyze the aesthetic feeling of this kind of style and the causal relationship between the whole works of art achievement? In general, people can take the following steps to finish the program.

\section{Analyze the Diction}

The meaning of words in a literary text is not limited to the definition in the dictionary. In the context of the constructed these words affect each other, so does their semantics. To describe the stylistic features of a writer words people have to research this mutual relationship between words and the resulting stylistic meaning. When reading a poem, a novel, people should firstly try to know who is the narrator, the author, or his (her) characters. Then, the reader should analyze the level of language used, standard, or nonstandard English. Besides, people should also understand the word, whether simple or not. Is it general or specific? Is an abstract noun or concrete noun? Is static verb or dynamic? Answers to these questions will help readers to grasp the writer language style.

The first paragraph of the following two paragraphs comes from Hemingway's A Farewell to Amts, and the second paragraph comes from the United States novelist Theodore The Titan quoted from Edgar v. Rogerts. Contrasting the two different language characteristics can make us further realize the tendency of wording of the writers is a part of their individual style feature.

[Hemingway]:

In the late summer of that year we lived in a house in a village that looked across the river and the plain to the mountains.

In the bed of the river there were pebbles and boulders, dry and white in the sun, and the water was clear and swiftly moving and blue in the channels.

Troops went by the house and down the road and the dust they raised pondered the leaves of the tress. (Hemingway, 1929, p. 76)

[Dreiser]:

From New York, Vermont, New Hampshire, Maine had come a strange company, earnest, patient, determined, unschooled in even the primer of refinement, hungry far something the significance of which, when they had it, they could not even guess, anxious to be called great, determined so to be without ever knowing how. (Dreiser, 1957, p. 248)

Hemingway's paragraph describes the scene of that summer, "our" inhabitation environment and forces 
going through there. The paragraph of Dreiser depicts the inner world of a group of strangers from the northeastern state of United States such as New York. Although the words the two excerpts used are suitable for their own themes, but their stylistics is obviously different. When making the material structure, Hemingway chose simple, clear, and specific words, such as: house, river, mountains, clear, swiftly moving, blue, and powdered. He made the scenery and process appear in front of the readers, making the person clear at a glance. This is a clear and plain style. While Dreiser chooses evaluative and abstract written language, such as, patient, determined, hungry, refinement, significance, etc. Those written languages show the psychological activity of the group of outsiders, and lead the reader go into the characters' hearts to visit their mood step by step.

\section{Analyze the Syntax}

Usually, the vocabulary of a work describes the character's thoughts and feelings through sentences and the phrases and there are many different ways of composition of the whole sentences and phrases. The grammar analysis with the purpose of stylistic study focuses on exploring the relationship between the type of sentences, phrases, and writer individuals. English sentences can be divided into a variety of English sentences according to its function, such as declarative sentence, interrogative sentences, imperative, and exclamatory sentences; and can be also divided into simple sentence, paratactic sentence, complex sentences, compound sentences, complete sentences, and elliptical sentence according to its structure; besides, English sentences can be divided into periodic-sentences, loose sentence, and parallel sentences according to the way of emphasizing sentence content. In addition, the word each other can match into different phrases, such as: noun groups, verbal phrases, prepositions, etc. These different sentences and phrases contain different stylistic effects. When analyzing the grammar structure, the author should read the text carefully, observe and record the dominated phrases, and explore the causes of writers' preference for them.

Now make the previous article quoted as an example to illustrate how to carry out the syntax analysis. Two thirds in the Hemingway's A Farewell to Amts are compound sentences. And one of the features of compound sentence is to use "and" to connect the components in the sentence. Hemingway fully grasp the characteristics and extensively use the "and". For example, there are five "and" in the short second sentence; they suggest the importance of the various parts of the sentence. This sentence pattern is usually used to state events and describe the scene. It is by this sentence pattern that Hemingway reappears faithfully the original characters in the novel. This narrative of Hemingway is objective, calm, and step by step, like a rippling stream, slow but continuous, plain but very clear, which is a gentle, simple, and realistic sketch style.

\section{Analyze Rhetorical}

Rhetoric is generally defined as the art of persuasive writing. Correct grammar can help the writer to express clearly, and appropriate rhetoric can make works more vivid and touching. The writer often obtains this effect with the help of figures of speech in his work. The commonly used English figures of speech include: simile, metaphor, analog, personification, metonymy, synecdoche, allusions, irony, and so on. These figures of speech mostly play a role based on the connotation and extension of the meaning, the aesthetic feelings of man, and other psychological forms. When making a rhetorical analysis, the reader should be sure the pattern of rhetorical and discourse preference for writer, and then discuss the stylistic effect the color brings to the work. They are associated with each other, and complement each other. Below is a script fragments Denmark's inner 
soliloquy selected from Shakespeare's Hamlet.

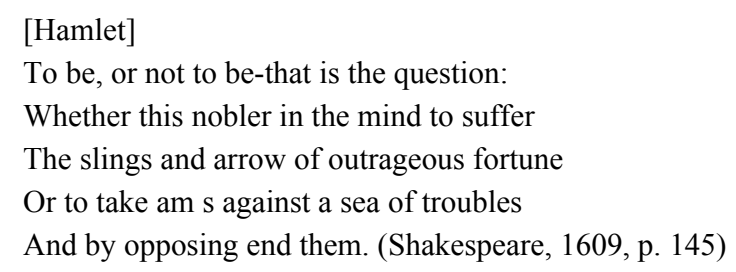

Hath not a Jew eyes? Hath not a Jew hands, organs, dimensions, senses, affections, passions?... If you prick us, do we not bleed? If you tickle us, do we not laugh? If you poison us, do we not die? And if you wrong us, shall we not revenge? (Shakespeare, 1600, p. 29)

In those a few lines of inner monologue extracted, choosing questions is the dominant pattern. Such sentence pattern ingeniously shows the swing state of mind of the hero. The dialogue at the start of the choice question consists of two verb infinitives, which seem to be simple, but actually to be Shakespeare's quality pen. The verb infinitive has the function of indicating the immediate action will happen from the perspective of grammar. Here, the author both use the affirmation and negation form of verb infinitive, suggesting that there is the possibility of survival and perish at the same time. Therefore, the urgency of answering this problem shows on the page. Then, two infinitive phrases with "whether" and "or" make up of the second choice alternative interrogation. The first one specifically puts forward a major and serious proposition, while the second shows the characters inner conflicts. Before and after the two sentences, closely linked, more let a person feel the imminent problem of hero. From the rhetorical perspective, the first one is concise and clear, giving a person the sense with straightforward; The second uses extensive metaphor whose meaning is deep, and shows the complex and heavy heart of the by his pen.

\section{Conclusion}

With the aid of image literature reflecting the colorful world, and expressing the writer's aesthetic feeling. Literary language is concise and beautiful with the effect of making people think deep and increasing the sense. Stylistics has a very strong explanatory power based on the analysis of the characteristics of language arts. Therefore, as a kind of methodology, stylistics can broaden the students whose major is English and American literature academic vision, and enrich the current British and American literature teaching. In view of the literature which is the art of language, and stylistics research across the two fields of linguistics and literature, there is reason to believe that stylistics in British and American literature teaching will have broad application prospects in the future.

\section{References}

Brumfit, C. J., \& Carter, R. A. (2000). Literature and language teaching. Oxford: Oxford University Press, \& Shanghai: Shanghai Foreign Languages Education Press.

Dreiser, T. (1957). The titan (p. 248). Moscow: Foreign Language Press.

Hemingway, E. M. (1929). A farewell to amts (p. 76). Shanghai: Shanghai Translation Publishing House.

Lazar, G. (2005). Literature and language teaching: A guide for teachers and trainers. Cambridge: Cambridge University Press. McRae, J. (1997). Literature with a small "l”. London: Macmillan/Prentice Hall.

Shakespeare, W. (1600). The merchant of Venice (p. 29). Shanghai: Shanghai Translation Publishing House. 
Shakespeare, W. (1602). Hamlet (p. 145). Shanghai: Shanghai Translation Publishing House.

Short, M. H., \& Candlin, C. N. (1986). Teaching study skills for English literature (pp. 160-166). Oxford: Oxford University Press. Widdowson, H. G. (1999). Practical stylistics (pp. 58-59). Oxford: Oxford University Press, \& Shanghai: Shanghai Foreign Languages Education Press. 